\title{
The Decrease in Farnesoid $X$ Receptor, Pregnane $X$ Receptor and Constitutive Androstane Receptor in the Liver after Intestinal Ischemia-Reperfusion
}

Jiro Ogura ${ }^{1}$, Yusuke Terada ${ }^{1}$, Takashi Tsujimoto ${ }^{1}$, Takahiro Koizumi ${ }^{1}$, Kaori Kuwayama ${ }^{1}$, Hajime Maruyama ${ }^{1}$, Asuka Fujikawa $^{1}$, Atsushi Takaya ${ }^{1}$, Masaki Kobayashi ${ }^{1}$, Shirou Itagaki ${ }^{1,3}$, Natsuko Takahashi ${ }^{2}$, Takeshi Hirano ${ }^{1,4}$, Hiroaki Yamaguchi ${ }^{1}$, Ken Iseki ${ }^{1}$

${ }^{1}$ Laboratory of Clinical Pharmaceutics \& Therapeutics, Division of Pharmasciences, Faculty of Pharmaceutical Sciences, Hokkaido University, Kita-12-jo, Nishi-6-chome, Kita-ku, Sapporo 060-0812, Japan

${ }^{2}$ Graduate School of Medicine, Hokkaido University

${ }^{3}$ Present address: Department of Pharmacy, Hirosaki University School of Medicine \& Hospital, Hirosaki, Japan

${ }^{4}$ Present address: Department of Pharmacy, Kobe University Hospital, Kobe, Japan

Received, March 14, 2012; Accepted, November 10, 2012; Published, November 13, 2012.

\begin{abstract}
Purpose. Intestinal ischemia-reperfusion (I/R) damages remote organs, including the liver, and promotes multi-organ failure (MOF). However, the molecular mechanisms underlying acute liver injury after intestinal I/R have not been completely elucidated. Farnesoid X receptor (FXR), pregnane X receptor (PXR) and constitutive androstane receptor (CAR) regulate metabolizing enzymes and transporters, and coordinately prevent hepatotoxicity reflecting an inability of appropriate excretion of endogenous toxic compounds. In this study, we assessed FXR, PXR and CAR expression levels and their localization levels in nuclei in the liver after intestinal I/R. We also investigated the effect of IL-6 on FXR, PXR and CAR expression levels and their localization levels in nuclei in in vitro experiments. Methods. We used intestinal $\mathrm{I} / \mathrm{R}$ model rats. Moreover, HepG2 cells were used in in vitro study. Real-time PCR and Western blotting were used to assess mRNA and protein expression levels. Nuclear receptor localization in nuclei was analyzed by Western blotting using nuclear extracts. Results. FXR and PXR expression levels began to be decreased at $3 \mathrm{~h}$, and FXR, PXR and CAR expression levels were decreased at $6 \mathrm{~h}$ after intestinal $\mathrm{I} / \mathrm{R}$. The localization levels of FXR, PXR and CAR in nuclei began to be decreased at $3 \mathrm{~h}$, and all of them were decreased at $6 \mathrm{~h}$ after intestinal $\mathrm{I} / \mathrm{R}$. In HepG2 cells, FXR, PXR and CAR expression levels were decreased by $0.5-1 \mathrm{ng} / \mathrm{mL}, 0.5-100 \mathrm{ng} / \mathrm{mL}$ and $100 \mathrm{ng} / \mathrm{mL}$ IL-6 treatment for $24 \mathrm{~h}$, respectively. FXR, PXR and CAR localization levels in nuclei were suppressed by $0.5-10$ $\mathrm{ng} / \mathrm{mL}, 10-100 \mathrm{ng} / \mathrm{mL}$ and 10-100 ng/mL IL-6 treatment for $24 \mathrm{~h}$, respectively. Conclusions. FXR, PXR and CAR expression levels are decreased in the liver after intestinal I/R. IL-6 is one of main causes the decreases in expressions of these receptors.
\end{abstract}

This article is open to POST-PUBLICATION REVIEW. Registered readers (see "For Readers") may comment by clicking on ABSTRACT on the issue's contents page.

\section{INTRODUCTION}

Intestinal ischemia-reperfusion $(\mathrm{I} / \mathrm{R})$ is a common clinical problem in small bowel transplantation, circulatory shock, and strangulation ileus. Intestinal $\mathrm{I} / \mathrm{R}$ causes gut dysfunction, characterized histologically by mucosal injury, decreased basement membrane integrity, and decreased barrier function (1). Additionally, intestinal mucosa damage induces local production of inflammatory cytokines. Therefore, intestinal $\mathrm{I} / \mathrm{R}$ damages remote organs, including the lung (2), kidney (3) and liver (4), as well as the intestine, and promotes multi-organ failure (MOF) (5). In the liver, sinusoidal and venular endothelial cell damage causes loss of hepatic vascular permeability barrier function (4). In addition, the levels of aspartate transaminase (AST) and

\footnotetext{
Corresponding Author: Ken Iseki, Ph. D., Laboratory of Clinical Pharmaceutics \& Therapeutics, Division of Pharmasciences, Faculty of Pharmaceutical Sciences, Hokkaido University, Kita-12-jo, Nishi-6-chome, Kita-ku, Sapporo, Japan, E-mail: ken-i@pharm.hokudai.ac.jp
} 
alanine transaminase (ALT) in serum are significantly increased after intestinal $\mathrm{I} / \mathrm{R}$ (6). Injury of the intestinal mucosa is induced by production of reactive oxygen species (7) and release of inflammatory cytokines (8). However, the molecular mechanisms underlying acute liver injury after intestinal I/R have not been completely elucidated.

The liver is responsible for a great portion of the body's metabolic needs including the synthesis and control of pathway involved in cholesterol, fatty acid, carbohydrate, amino acid, bile acids and metabolism / detoxification of drugs and xenobiotics. Therefore, the liver failure directly contributes the poor prognosis in intestinal I/R patients. Transporters and metabolic enzymes are pivotal roles in the metabolism/detoxification of endogeneous toxic compounds. Multi-drug resistance associated protein (MRP) 2 belongs to the ATP-binding cassette (ABC) transporter superfamily, and is abundant expression in the liver. MRP2 mainly effluxes organic anion compounds, such as bile acids, bilirubin, from liver to the outside of the body. In fact, Mrp2-deficient mouse is significantly increased the accumulation of organic anion compound in the liver (9).

Farnesoid X receptor (FXR), pregnane $X$ receptor (PXR) and constitutive androstane receptor (CAR) are members of the nuclear receptor superfamily, and are highly expressed in the liver. These receptors regulate several metabolizing enzymes and transporters, such as MRP2 (10-14), and coordinately prevent hepatotoxicity $(15,16)$. Disruption of FXR or PXR in mouse developed severe hepatotoxicity reflecting an inability of appropriate excretion of endogenous toxic compounds, such as bile acids, bilirubin, and cholesterol $(17,18)$. Moreover, FXR, PXR or CAR agonists prevent hapatotoxicity inducing bile acids, cholesterol (19-21). The increase in MRP2 expression much contributes to the effects of PXR or CAR agonists on the hepatotoxicity induced by endogeneous toxic compounds (21).

FXR, PXR and CAR expression levels are affected by inflammation. In fact, lipopolysaccharide (LPS) -induced inflammation is decreased the expression and function of nuclear receptors (22). LPS induces severe liver injury by the release of inflammatory cytokines including IL-6. Moreover, IL-6 mainly causes the decrease several metabolizing enzymes and transporters in LPS-induced inflammation (23). These findings suggest that IL-6 can affect the nuclear receptors expression, and causes liver injury in LPS-induced inflammation.

We previously reported that MRP2 expression in the liver was significantly decreased after intestinal $\mathrm{I} / \mathrm{R}$ (24). The decrease in MRP2 expression in the liver was associated with the increase in serum concentration of IL-6 (24). Therefore, we hypothesize that alterations of FXR, PXR and CAR expression levels cause liver injury after intestinal I/R, and IL-6 is important for the alteration of these nuclear receptors. In this study, we assessed FXR, PXR and CAR mRNA levels, their protein expression levels and their localization levels in nuclei in the liver after intestinal I/R. We also investigated the effect of IL-6 on FXR, PXR and CAR expression and function in in vitro experiments.

\section{MATERIALS AND METHODS}

\section{Chemicals}

IL-6 was purchased from Wako (Tokyo, Japan). $\left[{ }^{3} \mathrm{H}\right]$ Estrone-3-sulfate (E-3-S) (specific activity: 57.3 $\mathrm{Ci} / \mathrm{mmol}$ ) was purchased from Perkin Elmer (Boston, MA). All other reagents were the highest grade available and used without further purification.

\section{Animals}

Male Wistar rats, aged 6 weeks, were obtained from Jla (Tokyo, Japan). The rats were housed for at least 1 week at $23^{\circ} \mathrm{C}$ and $60 \pm 10 \%$ relative humidity, with a 12-h light/dark cycle (until reaching 250-350 g in weight). During the period of acclimatization, the rats were allowed free access to food and water. The experimental protocols were reviewed and approved by the Hokkaido University Animal Care Committee in accordance with the "Guide for the Care and Use of Laboratory Animals".

\section{Intestinal I/R model}

Surgical procedures were carried out as described in a previous report (24). The animals were anesthetized with sodium pentobarbital $(30 \mathrm{mg} / \mathrm{kg}$ body weight, i.p. injection). Through a midline laparotomy, each rat was subjected to $30 \mathrm{~min}$ of ischemia by ligating small anastomosing vessels and occluding the superior mesenteric artery (SMA). Reperfusion was induced by removing the clamp. The abdomen was sutured during reperfusion. Rats were killed under surgical anesthesia at 1, 3, 6 and $24 \mathrm{~h}$ after reperfusion. Liver was harvested just before killing. 


\section{Cell culture}

HepG2 cells were maintained in plastic culture flasks (Corning Costar Corp., Cambridge, MA). These stock cells were subcultivated before reaching confluence. HepG2 cells were kept in Dulbecco's modified Eagle's medium (Sigma Aldrich, Tokyo, Japan) with $10 \%$ fetal bovine serum (ICN Biomedicals, Inc., Aurora, $\mathrm{OH}$ ) and $1 \%$ penicillin-streptomycin at $37^{\circ} \mathrm{C}$ under $5 \% \mathrm{CO}_{2}-95 \%$ air at $37^{\circ} \mathrm{C}$. The cells were given fresh growth medium every 2 days. When the HepG2 cells had reached confluence, they were harvested with $0.25 \mathrm{mM}$ trypsin and $0.2 \%$ EDTA (0.5-1 min at $37^{\circ} \mathrm{C}$ ), resuspended, and seeded into a new flask. In the present study, HepG2 cells were used between passages 137-145. IL-6 was dissolved in water and added to cells at various concentrations for periods of 24 or $48 \mathrm{~h}$.

\section{Semi-quantitative real-time PCR}

Total RNA was prepared from liver of rats and HepG2 cells using an ISOGEN (Nippon Gene, Tokyo, Japan) and an RNase-Free DNase Set (QIAGEN, Tokyo, Japan). Single-strand cDNA was made from 2 $\mu \mathrm{g}$ total RNA by reverse transcription (RT) using a ReverTra Ace (TOYOBO, Osaka, Japan). Semi-quantitative real-time PCR was performed using an ABI PRISM 7700 Sequence Detector (Applied Biosystems, Foster City, CA) with Platinum $^{\circledR}$ SYBR $^{\circledR}$ Green qPCR SuperMix-UDG (Invitrogen, Carlsbad, CA) or an $\mathrm{Mx} 3000^{\mathrm{TM}}$ Real-time PCR System (STRATAGENE, Stratagene, La Jolla, CA) with GoTaq ${ }^{\circledR}$ qPCR Master Mix
(Promega, Madison, WI) as per the manufacturer's protocol, respectively. PCR was performed using rat FXR-specific primers, rat PXR-specific primers or human FXR-specific primers through 40 cycles of $95^{\circ} \mathrm{C}$ for $15 \mathrm{~s}, 50^{\circ} \mathrm{C}$ for $30 \mathrm{~s}$ and $72^{\circ} \mathrm{C}$ for $30 \mathrm{~s}$; using rat CAR-specific primers through 40 cycles of $95^{\circ} \mathrm{C}$ for $15 \mathrm{~s}, 51^{\circ} \mathrm{C}$ for $30 \mathrm{~s}$ and $72^{\circ} \mathrm{C}$ for $30 \mathrm{~s}$; using human CAR-specific primers through 40 cycles of $95^{\circ} \mathrm{C}$ for $15 \mathrm{~s}, 59^{\circ} \mathrm{C}$ for 5 or $10 \mathrm{~s}$ and $72^{\circ} \mathrm{C}$ for $30 \mathrm{~s}$; using human MRP2-specific primers or human PXR-specific primers through 40 cycles of $94^{\circ} \mathrm{C}$ for $15 \mathrm{~s}, 60^{\circ} \mathrm{C}$ for $30 \mathrm{~s}$ and $72^{\circ} \mathrm{C}$ for $30 \mathrm{~s}$; or using rat or human GAPDH-specific primers after pre-incubation at $95^{\circ} \mathrm{C}$ for $15 \mathrm{~min}$. The primers specific to $\mathrm{rFXR}$, rPXR, rCAR, rGAPDH, hMRP2, hFXR, hPXR, hCAR and hGAPDH were designed on the basis of sequences in the GenBank ${ }^{\mathrm{TM}}$ database (accession no.: U18374, AF151377, AB104736, AF106860, NM_000392, BC130573, BC017304, BC121120 and NM_002046, respectively). The sequences of the specific primers are shown in Table 1. The PCR products were normalized to amplified GAPDH, which was the internal reference gene (housekeeping gene). Standard curves were prepared for each target and housekeeping gene. The standard curve was established between the threshold cycles $(\mathrm{Ct})$ and the $\log _{10}$ (copy numbers) by using the Applied Biosystems sequence detection system software, version 1.9.1. The software calculates the relative amount of the target gene and the housekeeping gene based on the $\mathrm{Ct}$.

Table 1 Primer sequences for real-time PCR

\begin{tabular}{|c|c|c|c|c|}
\hline Name & $\begin{array}{l}\text { Accession } \\
\text { number }\end{array}$ & & Sequences & Product size \\
\hline $\mathrm{rFXR}$ & U18374 & $\begin{array}{l}\text { Forword } \\
\text { Reverce }\end{array}$ & $\begin{array}{l}\text { 5'-GCAACT GCG TGATGG ATATG-3' } \\
\text { 5'-TTC TCC CTG CAT AGC TTG GT-3' }\end{array}$ & 226 \\
\hline $\mathrm{rPXR}$ & AF151377 & $\begin{array}{l}\text { Forword } \\
\text { Reverce }\end{array}$ & $\begin{array}{l}\text { 5'-ATG TCT GAT GCC GCT GTG-3' } \\
\text { 5'-TCACTG TGAAAC ACC GCA-3' }\end{array}$ & 206 \\
\hline rCAR & AB104736 & $\begin{array}{l}\text { Forword } \\
\text { Reverce }\end{array}$ & $\begin{array}{l}\text { 5'-TGG CAT GAG GAAAGACAT GA-3' } \\
\text { 5'-AGG CCT GAACTG CAC AAACT-3' }\end{array}$ & 190 \\
\hline rGAPDH & AF106860 & $\begin{array}{l}\text { Forword } \\
\text { Reverce }\end{array}$ & $\begin{array}{l}\text { 5'-ATG GGAAGC TGG TCA TCAAC-3' } \\
\text { 5'-GTG GTT CAC ACC CAT CAC AA-3' }\end{array}$ & 221 \\
\hline hMRP2 & NM_000392 & $\begin{array}{l}\text { Forword } \\
\text { Reverce } \\
\end{array}$ & $\begin{array}{c}\text { 5'-ACA GAG GCT GGT GGC AAC C-3' } \\
\text { 5'-ACC ATT ACC TTG TCACTG TCC ATG A-3' }\end{array}$ & 227 \\
\hline$h F X R$ & BC130573 & $\begin{array}{l}\text { Forword } \\
\text { Reverce } \\
\end{array}$ & $\begin{array}{l}\text { 5'-GCA GAT CAG ACC GTG AAT GA-3' } \\
\text { 5'-GTT GCC ATT TCC GTG AAAAT-3' }\end{array}$ & 230 \\
\hline $\mathrm{hPXR}$ & BC017304 & $\begin{array}{l}\text { Forword } \\
\text { Reverce } \\
\end{array}$ & $\begin{array}{c}\text { 5'-GCA GGA GCAATT CGC CAT T-3' } \\
\text { 5'-TCG GTG AGCATAGCC ATGATC-3' }\end{array}$ & 102 \\
\hline hCAR & BC121120 & $\begin{array}{l}\text { Forword } \\
\text { Reverce } \\
\end{array}$ & $\begin{array}{l}\text { 5'-GCAAGA GGA GAT GGC ACT G-3' } \\
\text { 5'-AGC CAG CAG GCC TAG CAA C-3' }\end{array}$ & 100 \\
\hline hGAPDH & NM_002046 & $\begin{array}{l}\text { Forword } \\
\text { Reverce }\end{array}$ & $\begin{array}{l}\text { 5'-AAG GTC ATC CCT GAG CTG AA-3' } \\
\text { 5'-TTC TAG ACG GCA GGT CAG GT-3' }\end{array}$ & 95 \\
\hline
\end{tabular}




\section{Total protein extraction from rat liver}

Rat liver was homogenized in cold lysis buffer containing $1.0 \%$ Triton-X100, $0.1 \%$ SDS and $4.5 \mathrm{M}$ urea. The suspension was left to stand for $5 \mathrm{~min}$ and sonicated for $20 \mathrm{~min}$ at $4^{\circ} \mathrm{C}$. Then it was centrifuged at $12,100 \times \mathrm{g}$ for $15 \mathrm{~min}$ at $4^{\circ} \mathrm{C}$.

\section{Total protein extraction from HepG2 cells}

HepG2 cells were suspended in $1 \mathrm{~mL}$ of PBS and centrifuged at $700 \times \mathrm{g}$ for $5 \mathrm{~min}$ at $4{ }^{\circ} \mathrm{C}$. The resulting pellet was suspended in lysis buffer. The suspension was left to stand for $5 \mathrm{~min}$ and sonicated for $20 \mathrm{~min}$ at $4^{\circ} \mathrm{C}$. Then it was centrifuged at $12,100 \times \mathrm{g}$ for 15 $\min$ at $4^{\circ} \mathrm{C}$.

\section{Nuclear extraction from rat liver}

Nuclear extraction was carried out as described in a previous report with some modification (25). Rat liver was homogenized in solution 1 containing $0.6 \%$ Nonidet $^{\circledR} \quad$ P-40, $150 \mathrm{mM} \quad \mathrm{NaCl}, \quad 10 \mathrm{mM}$ $\mathrm{N}$-(2-hydroxyethyl) piperazine- $N$ '-2-ethanesulfonic acid (HEPES) (pH 7.9), $1 \mathrm{mM}$ EDTA and $0.5 \mathrm{mM}$ phenylmethylsulfonyl fluoride (PMSF). The homogenate was allowed to stand for $5 \mathrm{~min}$ on ice and centrifuged at $2,100 \times \mathrm{g}$ for $5 \mathrm{~min}$ at $4^{\circ} \mathrm{C}$, and the pellet was suspended in $50 \mu \mathrm{L}$ solution 2 containing $25 \%$ glycerol, $20 \mathrm{mM}$ HEPES (pH 7.9), $420 \mathrm{mM}$ $\mathrm{NaCl}, 1.2 \mathrm{mM} \mathrm{MgCl}_{2}, 0.2 \mathrm{mM}$ EDTA, $0.5 \mathrm{mM}$ dithiothreitol, $0.5 \mathrm{mM}$ PMSF, $2 \mathrm{mM}$ benzamidine, 5 $\mu \mathrm{g} / \mathrm{mL}$ pepstatin and leupeptin. The suspension was sonicated for $20 \mathrm{~min}$ at $4^{\circ} \mathrm{C}$ and centrifuged at $3,000 \times \mathrm{g}$ for $15 \mathrm{~s}$ at room temperature.

\section{Nuclear extraction from HepG2 cells}

HepG2 cells were suspended in $100 \mu \mathrm{L}$ solution 1 . The suspension was allowed to stand for $5 \mathrm{~min}$ on ice and centrifuged at $2,100 \times \mathrm{g}$ for $5 \mathrm{~min}$ at $4^{\circ} \mathrm{C}$, and the pellet was suspended in $50 \mu \mathrm{L}$ solution 2 . The suspension was sonicated for $20 \mathrm{~min}$ at $4^{\circ} \mathrm{C}$ and centrifuged at $3,000 \times \mathrm{g}$ for $15 \mathrm{~s}$ at room temperature.

\section{Western blot analysis}

Total protein extracts and nuclear extracts were prepared from rat liver or HepG2 cells. The protein concentrations of these samples in clear supernatant were determined by the method of Lowry et al. with bovine serum albumin as a standard (26). Each sample was denatured at $100^{\circ} \mathrm{C}$ for $3 \mathrm{~min}$ in a loading buffer containing $50 \mathrm{mM}$ Tris- $\mathrm{HCl}, 2 \%$ SDS, $5 \%$ 2-mercaptoethanol, 10\% glycerol, $0.002 \% \mathrm{BPB}$ and
3.6 $\mathrm{M}$ urea and separated on $4.5 \%$ stacking and $10 \%$ SDS polyacrylamide gels. Proteins were transferred electrophoretically onto nitrocellulose membranes at $15 \mathrm{~V}$ for $90 \mathrm{~min}$. The membranes were blocked with PBS containing $0.05 \%$ Tween 20 (PBS/T) and 10\% non-fat dry milk for $1 \mathrm{~h}$ at room temperature. After being washed with $\mathrm{PBS} / \mathrm{T}$, the membranes were incubated overnight at room temperature with a mouse monoclonal antibody to MRP2 (Abcam, Cambridge, UK) (diluted 1:50 or 100), a rabbit monoclonal antibody to FXR (Santa Cruz Biotechnology, Santa Cruz, CA) (diluted 1:500), a rabbit monoclonal antibody to PXR (Santa Cruz Biotechnology, Santa Cruz, CA) (diluted 1:500) or a rabbit monoclonal antibody to CAR (Santa Cruz Biotechnology, Santa Cruz, CA) (diluted 1:250) and washed three times with PBS/T for 10 min each time. The membranes were subsequently incubated for $1 \mathrm{~h}$ at room temperature with horseradish peroxidase-conjugated goat anti-mouse secondary antibody (Santa Cruz Biotechnology, Santa Cruz, CA) or horseradish peroxidase-conjugated goat anti-rabbit secondary antibody (Santa Cruz Biotechnology, Santa Cruz, CA) at a dilution of 1:2,000 and washed three times with PBS/T for 10 min each time. The bands were visualized by enhanced chemiluminescence according to the instructions of the manufacturer (Amersham Biosciences Corp., Piscataway, NJ).

\section{Measurement of IL-6 level in the liver}

Measurement of IL-6 level in the liver was carried out as described in a previous report with some modification (27). For the measurement, the liver tissue was homogenized in PBS containing $2 \mathrm{mM}$ PMSF, $5 \mu \mathrm{g} / \mathrm{mL}$ pepstatin and $5 \mu \mathrm{g} / \mathrm{mL}$ leupeptin. The homogenates were centrifuged at $10,000 \times \mathrm{g}$ for $45 \mathrm{~min}$ at $4^{\circ} \mathrm{C}$. The supernatants aliquoted and stored at $-80^{\circ} \mathrm{C}$. IL- 6 was measured by ELISA with rat IL-6 kit (BioSource Int. Inc., CA, USA) as recommended.

\section{Accumulation study}

After removal of the growth medium, cells were washed with Hank's Buffered Salt Solution (HBSS) -HEPES (pH 7.4) buffer (25 mM D-glucose, $137 \mathrm{mM}$ $\mathrm{NaCl}, 5.37 \mathrm{mM} \mathrm{KCl}, 0.3 \mathrm{mM} \mathrm{Na} \mathrm{HPO}_{4}, 0.44 \mathrm{mM}$ $\mathrm{KH}_{2} \mathrm{PO}_{4}, 4.17 \mathrm{mM} \mathrm{NaHCO}, 1.26 \mathrm{mM} \mathrm{CaCl} 2,0.8$ $\mathrm{mM} \mathrm{MgSO}_{4}$ and $10 \mathrm{mM}$ HEPES) and preincubated at $37^{\circ} \mathrm{C}$ for $10 \mathrm{~min}$ with $0.5 \mathrm{~mL}$ of HBSS-HEPES (pH7.4) buffer. Uptake was initiated by applying 
HBSS-HEPES (pH 7.4) buffer containing $5 \mathrm{nM}\left[{ }^{3} \mathrm{H}\right]$ E-3-S. The uptake study was performed at $37^{\circ} \mathrm{C}$ for $30 \mathrm{~min}$. After a predetermined time period, uptake was terminated by suctioning off the applied solution and immersing the plates in ice-cold HBSS-HEPES (pH 7.4) buffer. To quantify the radioactivity of $\left[{ }^{3} \mathrm{H}\right]$ E-3-S taken up by the cells, the cells were solubilized in $1 \% \mathrm{SDS} / 0.2 \mathrm{~N} \mathrm{NaOH}$. The remainder of the sample was mixed with $5 \mathrm{~mL}$ of scintillation cocktail (ASCII, Amersham Biosciences Corp., Piscataway, NJ, U.S.A.) to measure the radioactivity in a liquid scintillation counter (Packard, 1600TR). The cellular protein content was determined by the method of BCA protein assay with bovine serum albumin as a standard.

\section{Data analysis}

Statistical significance was evaluated using Dunnett's test (in vitro experiments except for accumulation study of the treatment of IL-6 for 24 h) or Duncan's test (accumulation study of the treatment of IL- 6 for $24 \mathrm{~h}$ and in vivo experiments). A value of $\mathrm{p}<0.05$ was considered significant.

\section{RESULTS}

\section{FXR, PXR and CAR expression after intestinal $\mathbf{I} / \mathbf{R}$}

First, we assessed FXR, PXR and CAR expression after intestinal $\mathrm{I} / \mathrm{R}$ in the liver. FXR mRNA level was decreased at 3-6 h after intestinal I/R (Fig. 1). PXR level mRNA was decreased at 3-24 h after intestinal I/R (Fig. 1). CAR mRNA level was decreased at 1-24 $\mathrm{h}$ after intestinal $\mathrm{I} / \mathrm{R}$. FXR protein expression level was 0.62 -fold and 0.78 -fold decreased at 3 and $6 \mathrm{~h}$, respectively, and 1.6-fold increased at $24 \mathrm{~h}$ after intestinal I/R (Fig. 2). PXR protein expression level was 0.74 -fold and 0.55 -fold decreased at 3 and $6 \mathrm{~h}$ after intestinal I/R, respectively (Fig. 2). CAR protein expression level was 0.63 - and 0.58 -fold decreased at 6 and $24 \mathrm{~h}$ after intestinal I/R, respectively (Fig. 2). FXR level in nuclei was 0.75 -fold decreased at $6 \mathrm{~h}$ after intestinal I/R and 1.4-fold increased at $24 \mathrm{~h}$ (Fig. 3). PXR level in nuclei was 0.61 -fold decreased at $6 \mathrm{~h}$ after intestinal I/R (Fig. 3). CAR level in nuclei was 0.67 - and 0.40-fold decreased at 6 and $24 \mathrm{~h}$, respectively (Fig. 3). At $6 \mathrm{~h}$ after intestinal I/R, FXR, PXR and CAR mRNA levels, protein expression levels and localization levels in nuclei were decreased.

\section{Amount of IL-6 in the liver after intestinal I/R}

Serum concentration of IL- 6 was increased at 3 (Supplementary figure 1) and $6 \mathrm{~h}$ (24) after intestinal $\mathrm{I} / \mathrm{R}$. However, it is not clarified whether production of IL- 6 in the liver is increased. Thus, we measured the amount of IL- 6 in the liver after intestinal I/R. The amount of IL- 6 in the liver was significantly increased at $3 \mathrm{~h}$, and that was highest at $6 \mathrm{~h}$ after intestinal I/R (Fig. 4). However, the increase of IL-6 in the liver at $6 \mathrm{~h}$ was not statistically significant because the amount of IL- 6 in the liver was slightly increased at $6 \mathrm{~h}$ in sham-operated rats. The amount of IL-6 in the liver was recovered at $24 \mathrm{~h}$ after intestinal I/R (Fig. 4).

\section{Effect of IL-6 on FXR, PXR and CAR expression}

Next, we investigated whether IL-6 affected FXR, PXR and CAR expression. First, we confirmed that MRP2, which is a target gene of FXR, PXR and CAR, was affected by IL-6. MRP2 mRNA level (Fig. 5A) and protein expression level (Fig. 5B) were decreased by IL- 6 treatment for $24 \mathrm{~h}$. Moreover, the treatment of IL-6 for $24 \mathrm{~h}$ increased the accumulation of E-3-S, which is a typical substrate of MRP2. In the inhibited MRP2 function by MK 571, which is a typical inhibitor of MRP2, the effect of the treatment of IL-6 for $24 \mathrm{~h}$ on the accumulation of E-3-S was diminished. These results suggested that the increase in accumulation of E-3-S by IL-6 treatment for $24 \mathrm{~h}$ was caused by the decreased MRP2 expression. MRP2 expression and function were recovered by IL-6 treatment for $48 \mathrm{~h}$ (Fig. 5).

Next, we assessed the effect of IL-6 on FXR, PXR and CAR expression. The treatment of IL-6 for $24 \mathrm{~h}$ decreased FXR, PXR and CAR mRNA levels (Fig. 6). Although, FXR mRNA level was decreased in a concentration-dependent manner by IL-6 treatment for $24 \mathrm{~h}$, FXR protein expression level was decreased by 0.5 or $1 \mathrm{ng} / \mathrm{mL}$ IL- 6 treatment for $24 \mathrm{~h}$, but was not altered by 10 or $100 \mathrm{ng} / \mathrm{mL}$ IL-6 treatment for $24 \mathrm{~h}$ (Fig. 7). PXR and CAR protein expression levels were decreased in a concentration-dependent manner by IL-6 treatment for $24 \mathrm{~h}$ (Fig. 7). FXR level in nuclei was decreased by $0.5-10 \mathrm{ng} / \mathrm{mL}$ IL-6 treatment for $24 \mathrm{~h}$ (Fig. 8). PXR and CAR levels in nuclei were decreased in nuclei was decreased in a concentration-dependent manner by IL-6 treatment for $24 \mathrm{~h}$ (Fig. 8). 

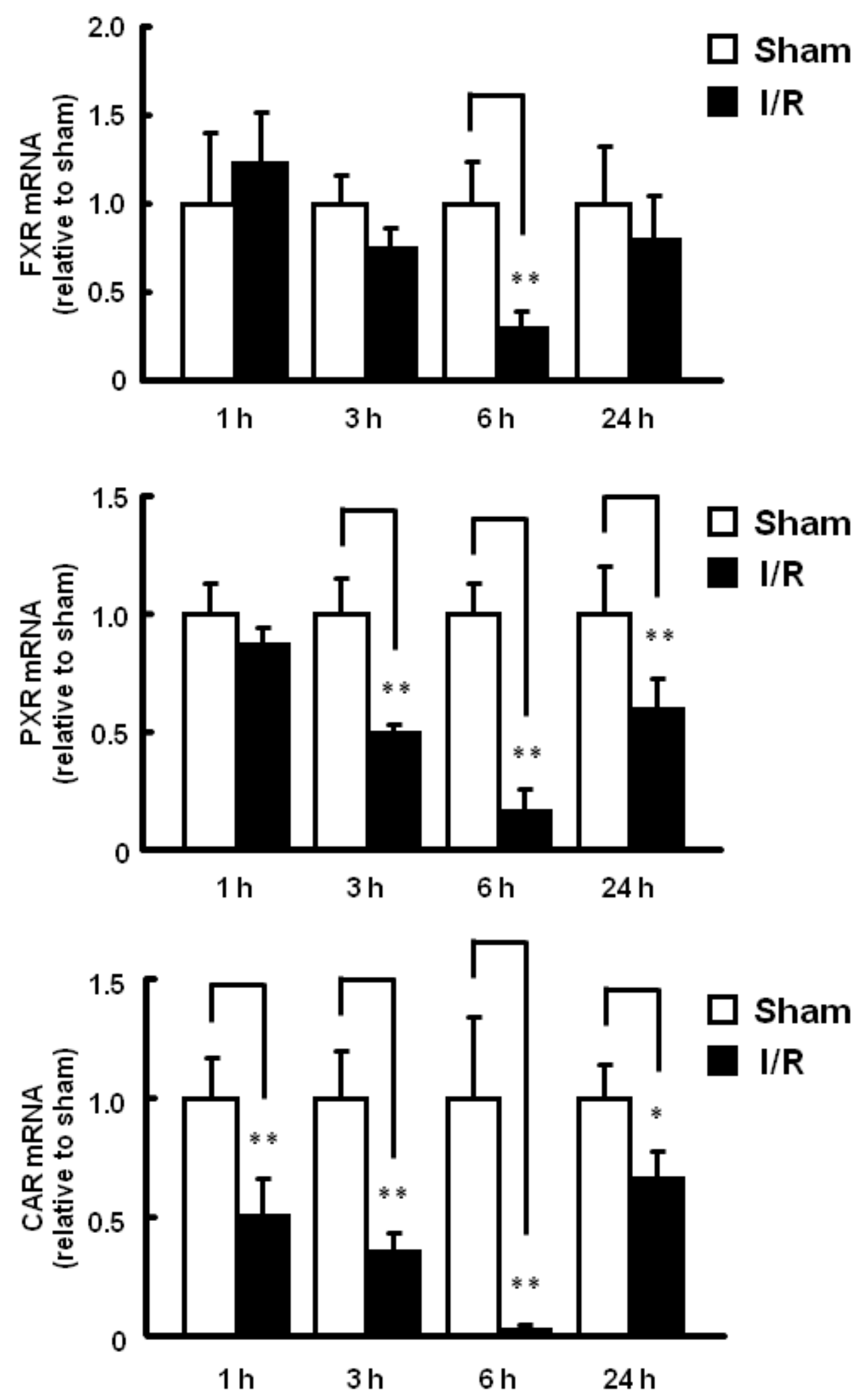

Figure 1. Time courses of FXR, PXR and CAR mRNA levels in the liver after intestinal $\mathrm{I} / \mathrm{R}$. Each column represents the mean with S.D. of 3-5 measurements. ${ }^{*} ; \mathrm{P}<0.05$ significantly different from sham, ${ }^{* *} ; \mathrm{P}<0.01$. 

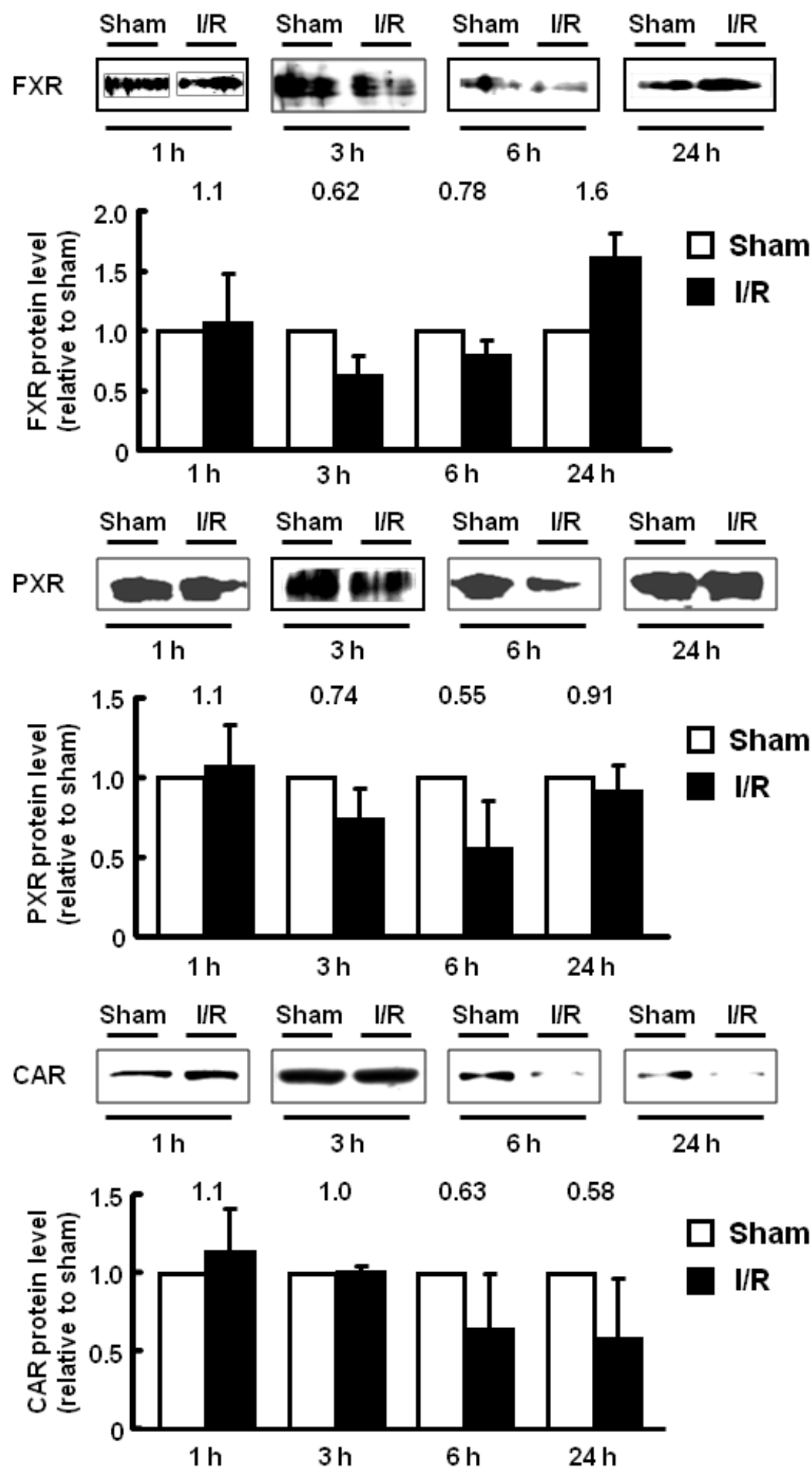

Figure. 2. Time courses of FXR, PXR and CAR protein expression in the liver after intestinal I/R. Whole cell lysates of the liver at 1, 3,6 and $24 \mathrm{~h}$ after intestinal $\mathrm{I} / \mathrm{R}$ were used for Western blot analysis. Western blot band intensity was determined by densitometry using Scion image program. Each column represents the mean with S.D. of 3-5 measurements. 

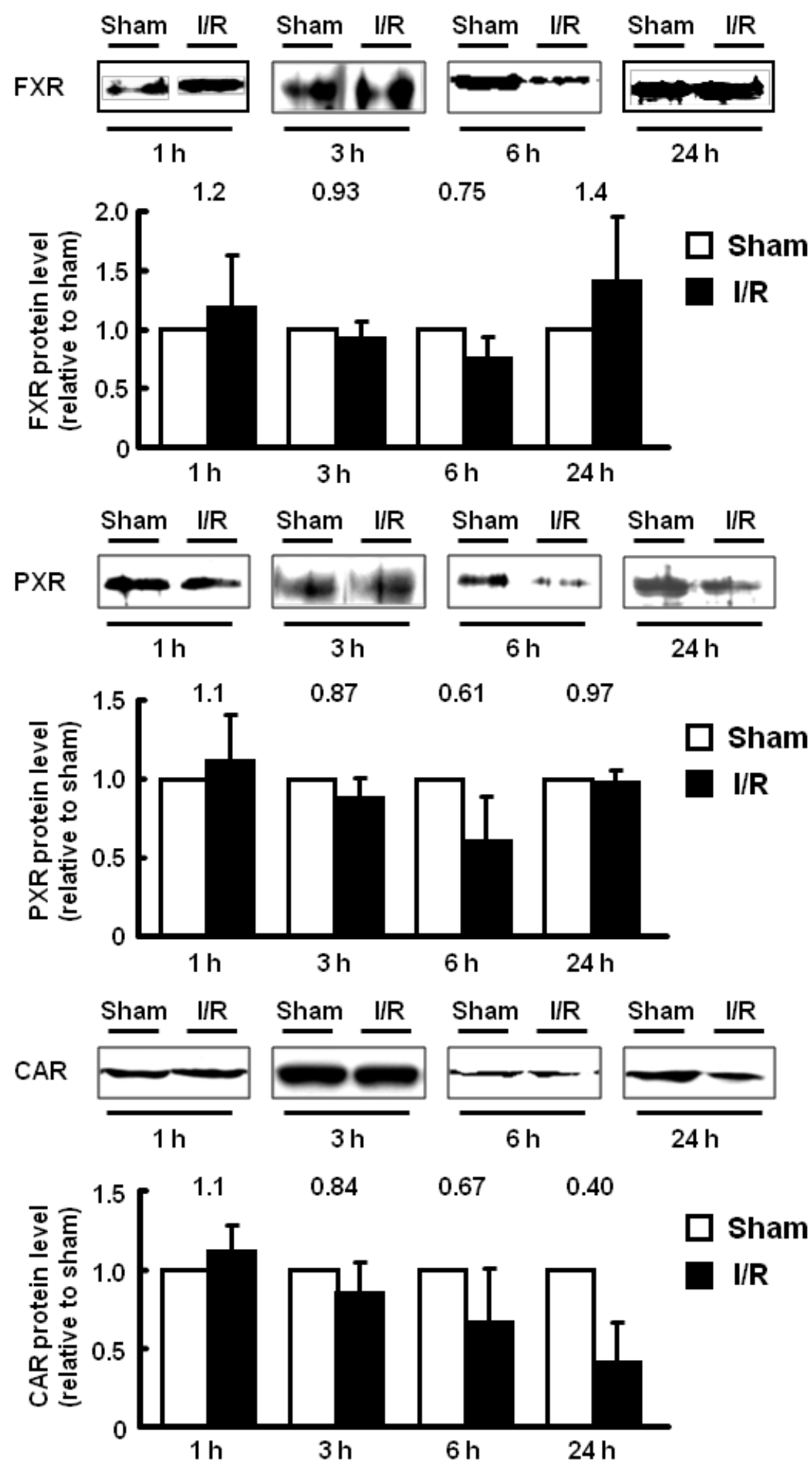

Figure. 3. Time courses of FXR, PXR and CAR levels in nuclei in the liver after intestinal I/R. Nuclear extracts of the liver at 1, 3, 6 and $24 \mathrm{~h}$ after intestinal $\mathrm{I} / \mathrm{R}$ were used for Western blot analysis. Western blot band intensity was determined by densitometry using Scion image program. Each column represents the mean with S.D. of 3-5 measurements. 


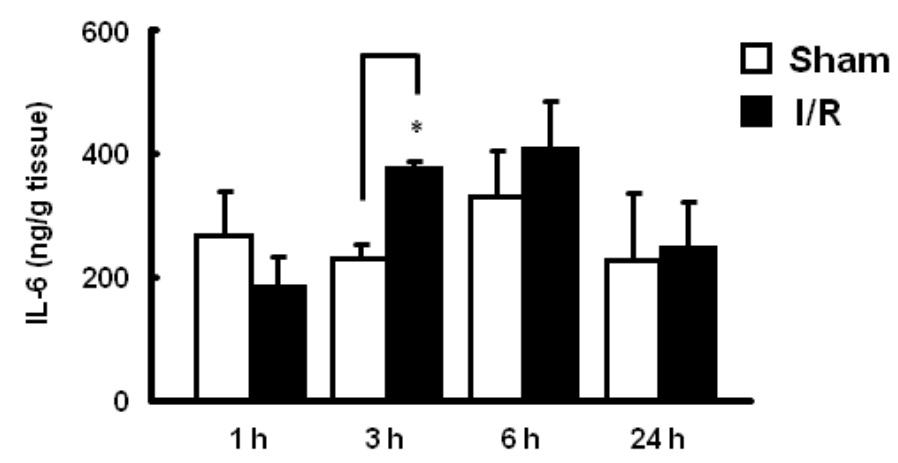

Figure 4. Time courses of amount of IL-6 in the liver homogenate after intestinal I/R. Each column represents the mean with S.D. of 3 measurements. *; $\mathrm{P}<0.05$ significantly different from sham.

Although PXR and CAR mRNA levels were still decreased by IL-6 treatment for 48 h (Fig. 6), FXR, PXR and CAR protein expression levels and the localization levels in nuclei were recovered by IL-6 treatment for $48 \mathrm{~h}$ (Figs. 7-8).

\section{DISCUSSION}

The purpose of this study was to determine the effect of intestinal I/R on FXR, PXR and CAR function in the liver. FXR, PXR and CAR are known to activate transcription of target genes in nuclei. Therefore, we investigated FXR, PXR and CAR expression levels and localization levels in nuclei.

FXR and PXR expression levels and localization levels in nuclei began to be decreased at $3 \mathrm{~h}$, and all of FXR, PXR and CAR were decreased at $6 \mathrm{~h}$ (Figs. 1-3). These results were associated with MRP2 expression level during 1-6 h after intestinal $\mathrm{I} / \mathrm{R}$ (supplementary figure 2 and previous report (24)), which is a target gene of FXR, PXR and CAR, indicating that intestinal $\mathrm{I} / \mathrm{R}$ suppressed the activity of FXR, PXR and CAR. IL- 6 is biosynthesized in the various cells such as macrophages, and then released from the intracellular to the extracellular space, where it exert its biological actions by binding to IL- 6 receptor. At 3 and $6 \mathrm{~h}$ after intestinal I/R, the amount of IL-6 in the liver homogenates were increased by 376.32 and $408.01 \mathrm{ng} / \mathrm{g}$ tissue, respectively. As well as serum concentration of IL-6, the increase in the amount of IL- 6 in the liver homogenate was associated with the decrease in the expression of MRP2, FXR, PXR and CAR during 1-6 $\mathrm{h}$ after intestinal $\mathrm{I} / \mathrm{R}$. These results suggested that IL-6 is one of main causes of the decrease in MRP2,
FXR, PXR and CAR expression levels. We previously reported the alteration of malondialdehyde (MDA) level, which is a marker of organ injury after $\mathrm{I} / \mathrm{R}$, in the liver (28). The increase in MDA level was associated with the increase in IL-6 and with the decrease in MRP2, FXR, PXR and CAR expression levels, suggesting that the decrease in FXR, PXR and CAR expression levels, at least in part, might be caused the liver injury after intestinal $\mathrm{I} / \mathrm{R}$. Furthermore, we demonstrated that FXR, PXR and CAR localization levels in nuclei were suppressed by 0.5-10 ng/mL, 10-100 ng/mL and 10-100 ng/mL IL-6 treatment for $24 \mathrm{~h}$, respectively, and MRP2 expression level was decreased by $10-100 \mathrm{ng} / \mathrm{mL}$ IL-6 treatment for $24 \mathrm{~h}$. These results also suggest IL-6, at least in part, participated with the suppression of FXR, PXR CAR activities and the decrease in MRP2 expression level. In HepG2 cells which were treated by IL- 6 for $24 \mathrm{~h}$, MRP2 expression level was not rigorously associated with FXR, PXR and CAR expression levels. However, one was decreased at least among FXR, PXR and CAR at the IL-6 concentration that decreased MRP2 expression level. Thus, we suggested that FXR, PXR and CAR coordinately regulate the MRP2 transcription. This suggestion is confirmed by the funding that FXR, PXR and CAR regulate several metabolizing enzymes and transporters, and coordinately prevent hepatotoxicity $(15,16)$.

On the other hand, the recovery of FXR, PXR and CAR expression levels during 6-24 h after intestinal $\mathrm{I} / \mathrm{R}$ were not associated with the recovery of MRP2 expression level. At $24 \mathrm{~h}$ after intestinal I/R, MRP2 expression level was recovered (24). 
(A)

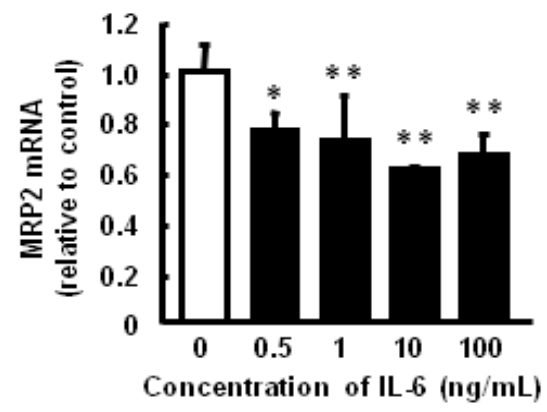

(B)

MRP2

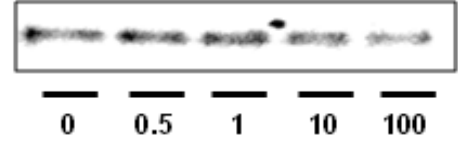

Concentration of IL -6 (ng/mL)

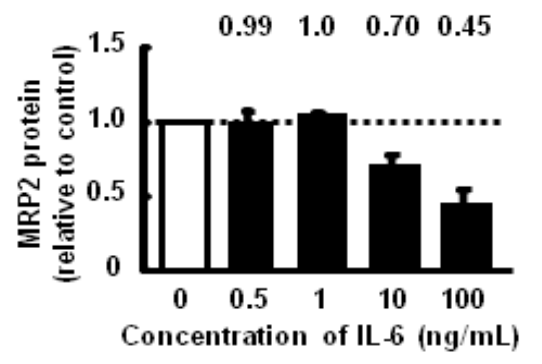

(C)

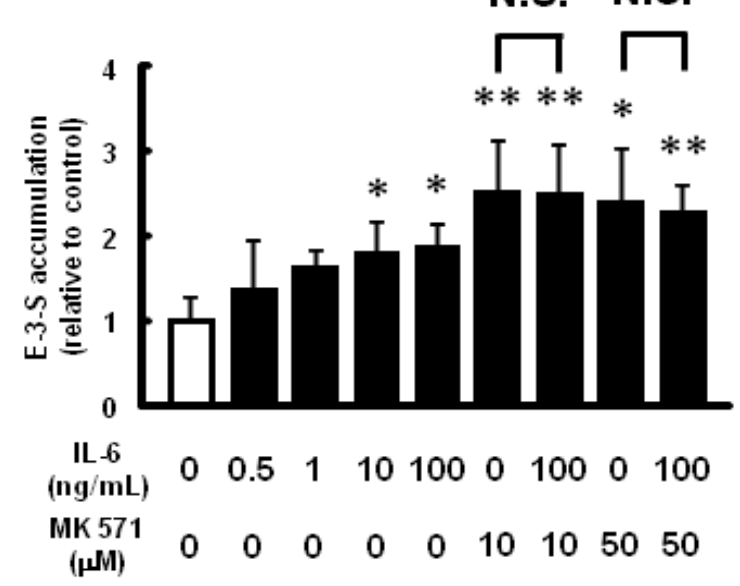

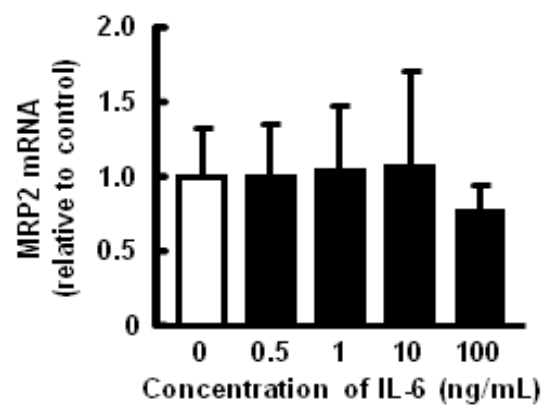

MRP2

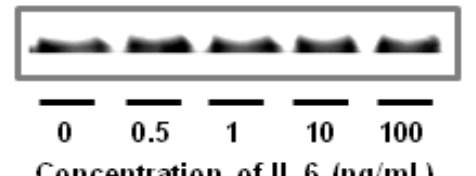

Concentration of IL $-6(\mathrm{ng} / \mathrm{mL})$
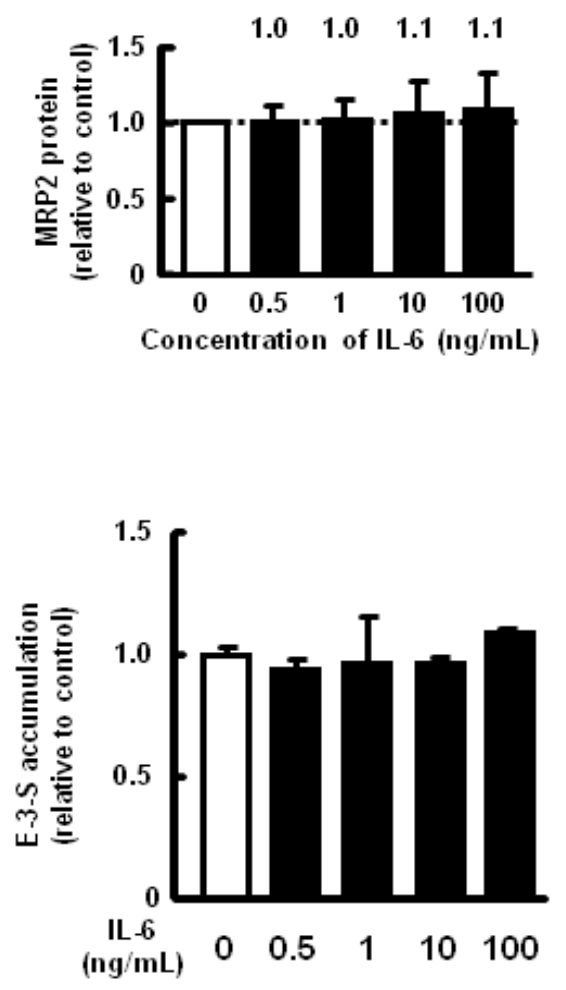

Figure 5. Effects of IL-6 on MRP2 mRNA level (A), protein expression (B) and E-3-S accumulation (C) in HepG2 cells. (A) Measurement of MRP2 mRNA level by real-time PCR. Each column represents the mean with S.D. of 3-7 measurements. (B) Analysis of MRP2 protein expression by Western blotting. Western blot band intensity was determined by densitometry using Scion image program. Each column represents the mean with S.D. of 3-4 measurements. (C) Analysis of E-3S accumulation. Each column represents the mean with S.D. of 3-4 measurements. HepG2 cells were exposed to $0-100 \mathrm{ng} / \mathrm{mL}$ IL-6 for $24 \mathrm{~h}$ (left side panels) or $48 \mathrm{~h}$ (right side panels). Control was incubated in a medium for $24 \mathrm{~h}$ (left side panels) or $48 \mathrm{~h}$ (right side panels). *; $\mathrm{P}<0.05$ significantly different from the control, **; $\mathrm{P}<0.01$, N.S.; not significant. 

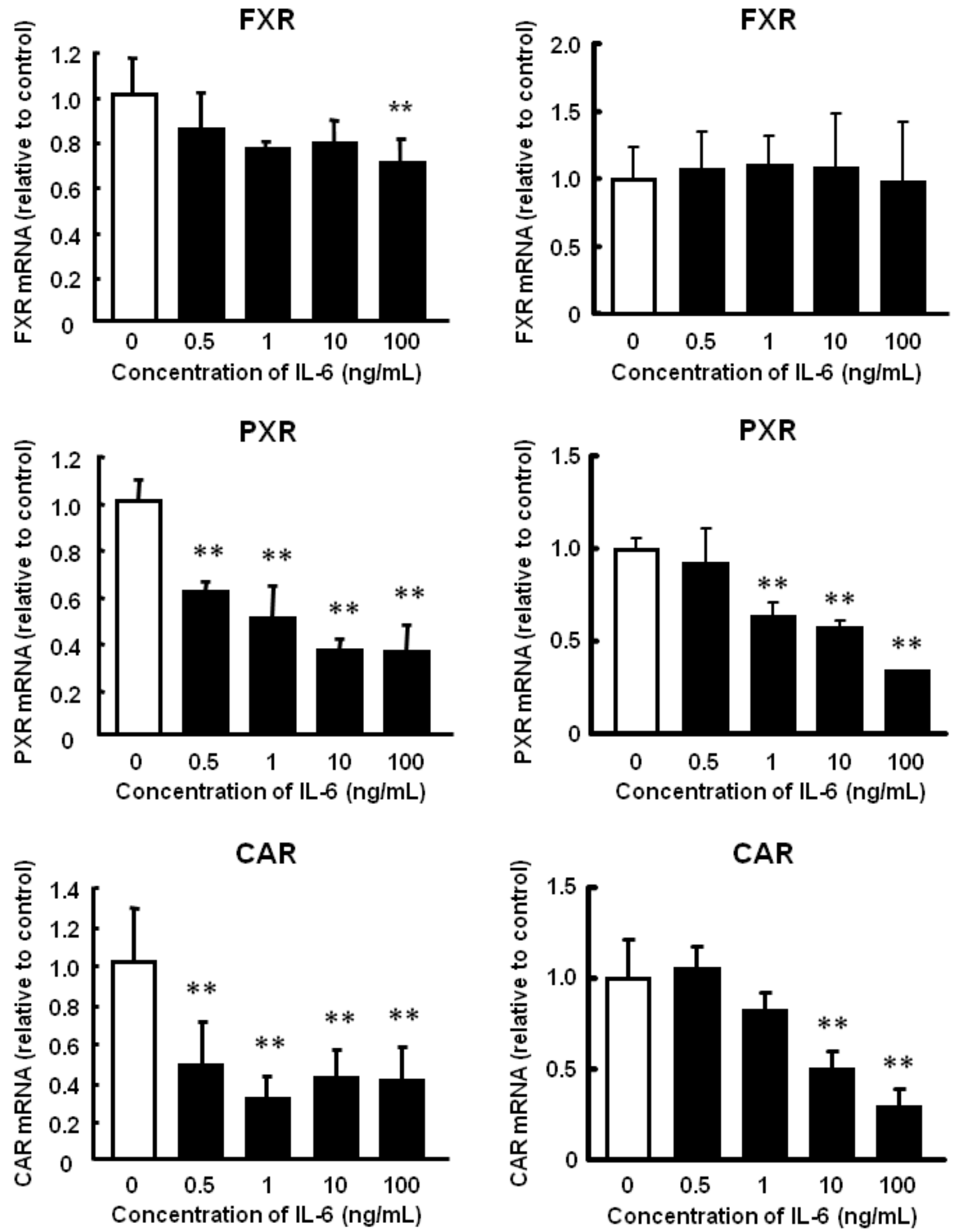

Figure 6. Effects of IL-6 on FXR, PXR and CAR mRNA levels in HepG2 cells. HepG2 cells were exposed to 0-100 ng/mL IL-6 for $24 \mathrm{~h}$ (left side panels) or $48 \mathrm{~h}$ (right side panels). Control was incubated in a medium for $24 \mathrm{~h}$ (left side panels) or $48 \mathrm{~h}$ (right side panels). Each column represents the mean with S.D. of 3-7 measurements. ${ }^{* *}$; P<0.01 significantly different from the control. 


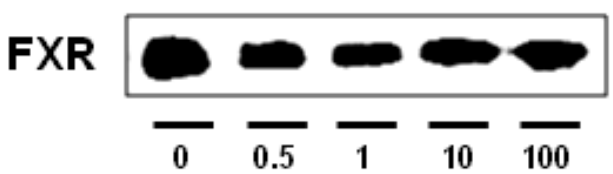

Concentration of IL-6 (ng/mL)

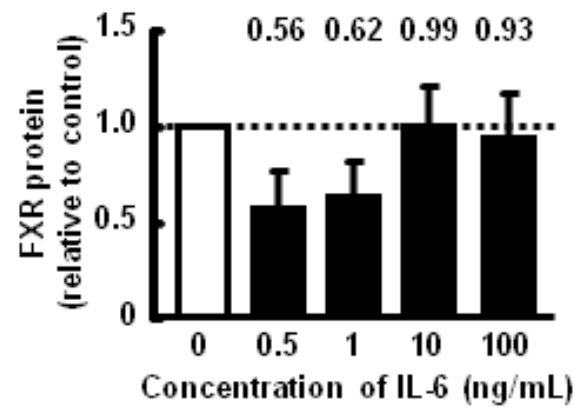

PXR

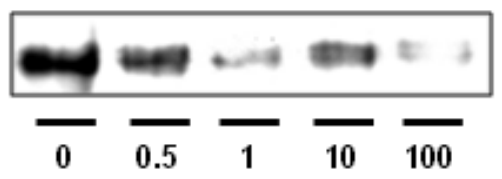

Concentration of IL -6 (ng/mL)

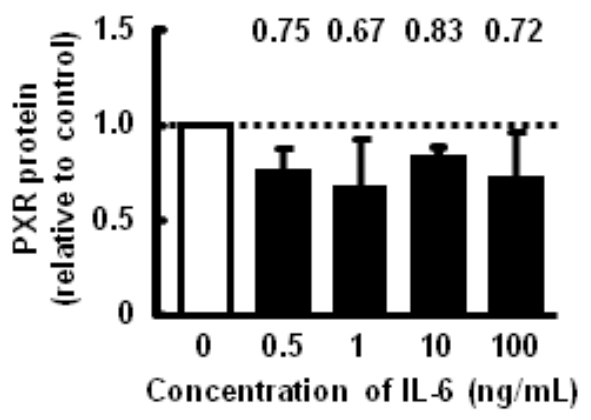

CAR

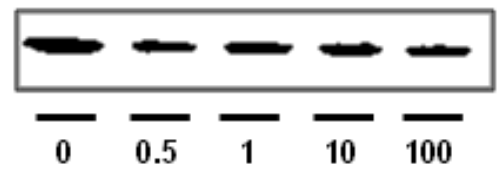

Concentration of IL -6 (ng/mL)

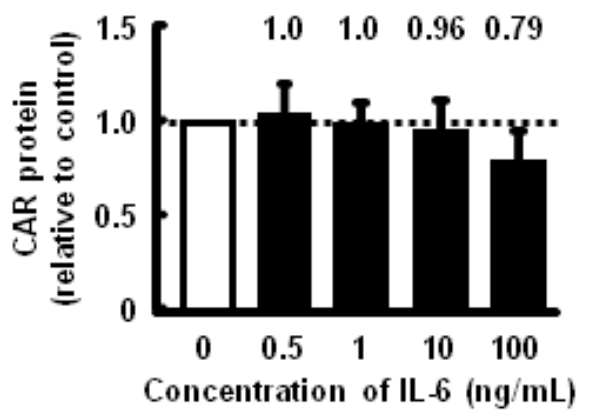

FXR
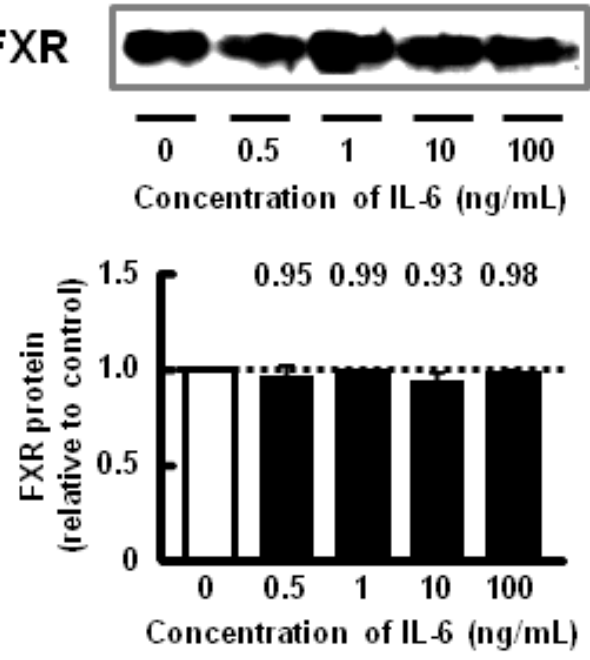

PXR

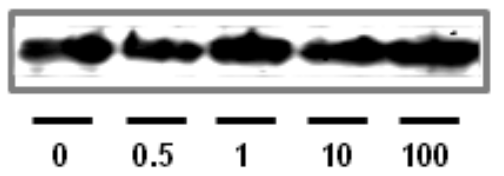

Concentration of IL $-6(\mathrm{ng} / \mathrm{mL})$

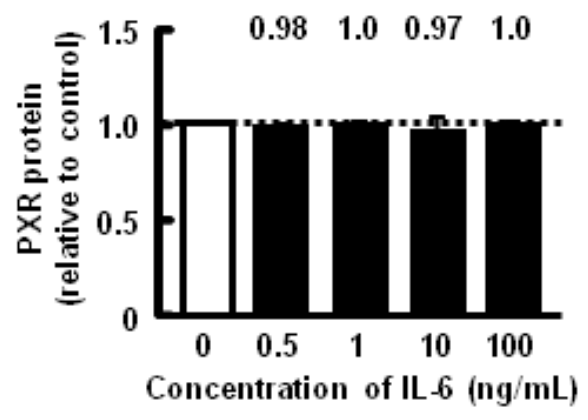

CAR

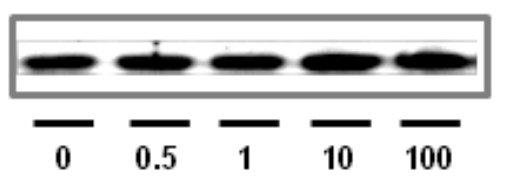

Concentration of IL -6 (ng/mL)

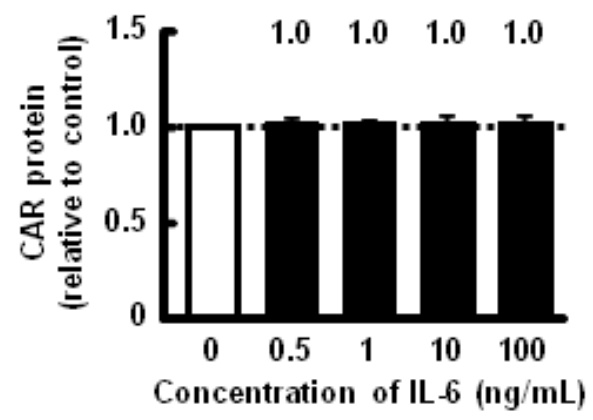

Figure 7. Effects of IL-6 on FXR, PXR and CAR protein expression in HepG2 cells. HepG2 cells were exposed to 0-100 ng/mL IL-6 for $24 \mathrm{~h}$ (left side panels) or $48 \mathrm{~h}$ (right side panels). Control was incubated in a medium for $24 \mathrm{~h}$ (left side panels) or $48 \mathrm{~h}$ (right side panels). HepG2 cell lysates used for Western blot analysis. Western blot band intensity was determined by densitometry using Scion image program. Each column represents the mean with S.D. of 3-4 measurements. 
FXR

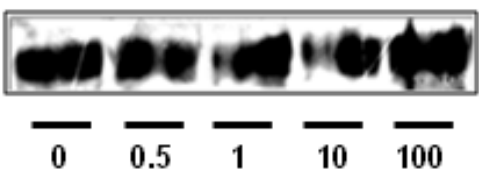

Concentration of IL $-6(\mathrm{ng} / \mathrm{mL})$

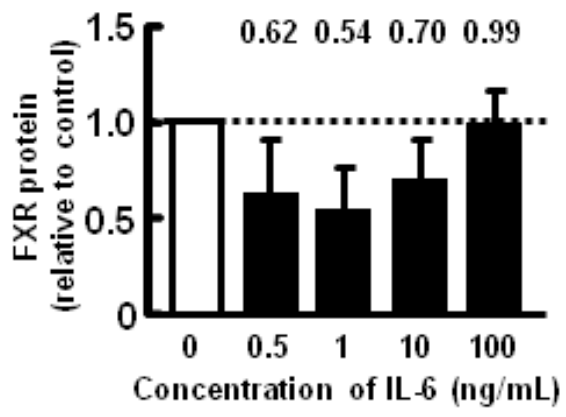

PXR

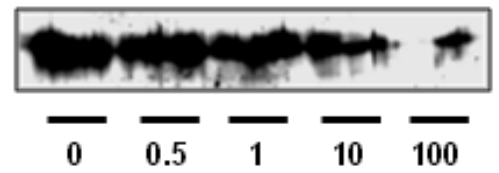

Concentration of IL $-6(\mathrm{ng} / \mathrm{mL})$

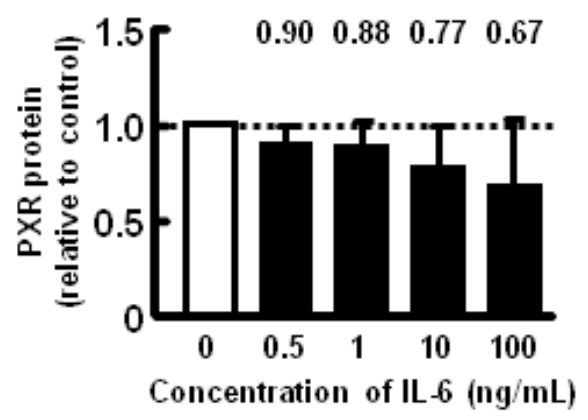

CAR

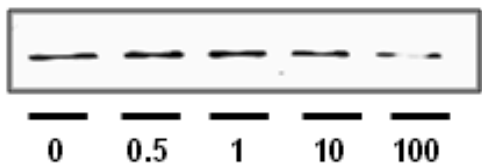

Concentration of IL- $6(\mathbf{n g} / \mathrm{mL})$

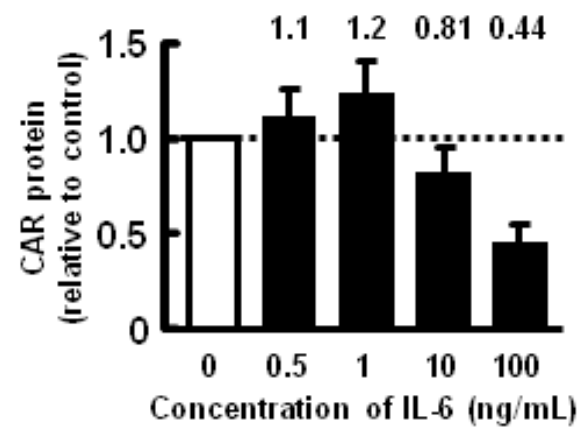

FXR

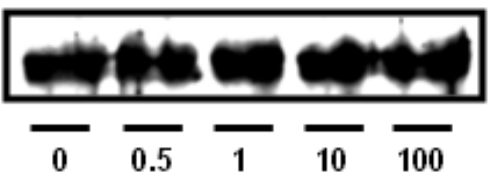

Concentration of IL $-6(\mathrm{ng} / \mathrm{mL})$

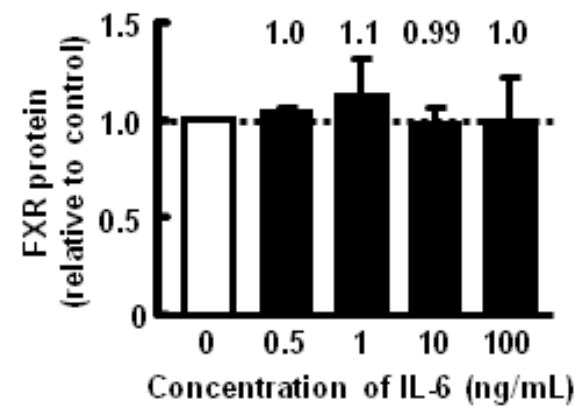

PXR

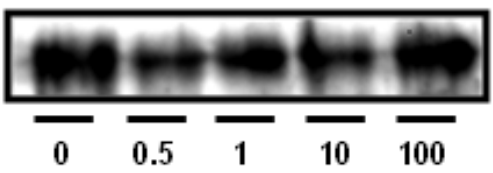

Concentration of IL-6 $(\mathrm{ng} / \mathrm{mL})$

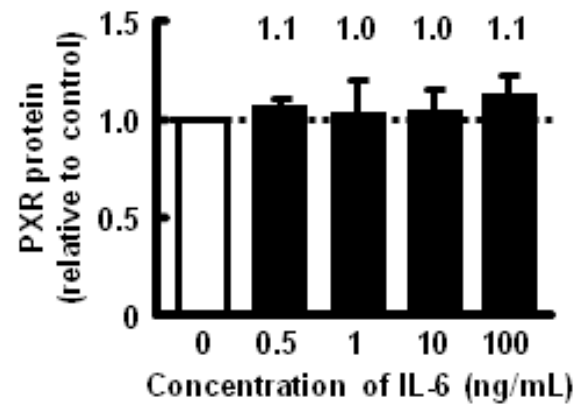

CAR

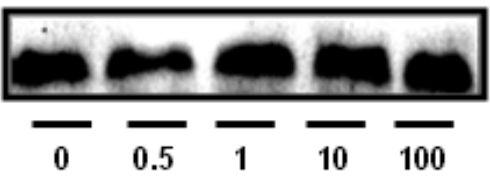

Concentration of IL- $6(\mathrm{ng} / \mathrm{mL})$

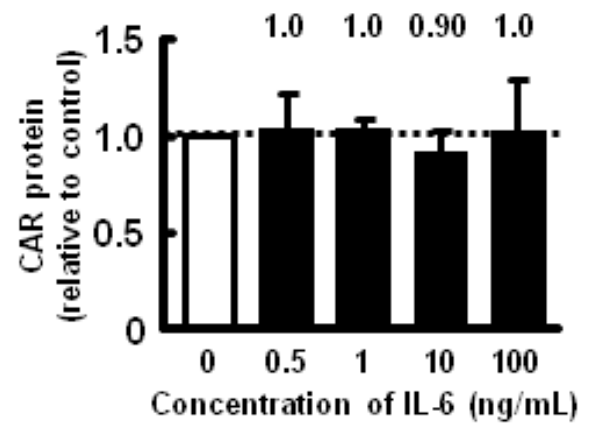

Figure 8. Effects of IL-6 on FXR, PXR and CAR levels in nuclei in HepG2 cells. HepG2 cells were exposed to 0-100 $\mathrm{ng} / \mathrm{mL}$ IL-6 for $24 \mathrm{~h}$ (left side panels) or $48 \mathrm{~h}$ (right side panels). Control was incubated in a medium for $24 \mathrm{~h}$ (left side panels) or $48 \mathrm{~h}$ (right side panels). Nuclear extracts of HepG2 cells used for Western blot analysis. Western blot band intensity was determined by densitometry using Scion image program. Each column represents the mean with S.D. of 3-5 measurements. 


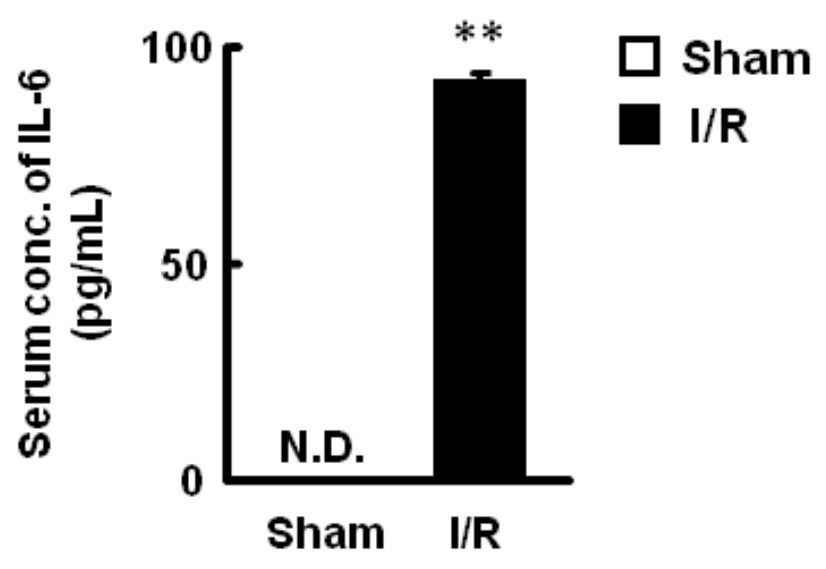

Supplementary Figure 1. Serum concentration of IL-6 at $3 \mathrm{~h}$ after intestinal I/R. Each column represents the mean and S.D. of 3-4 measurements. Statistical significance was evaluated using Student's t-test. **; P<0.01 significantly different from sham. N.D.; not detect.

\section{(A) mRNA level}

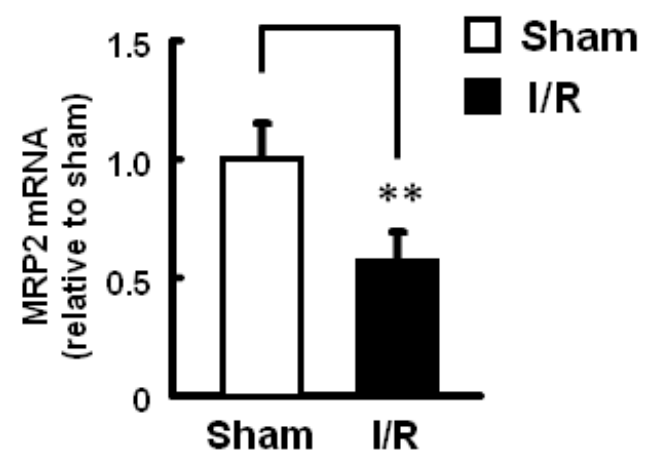

(B) Protein expression

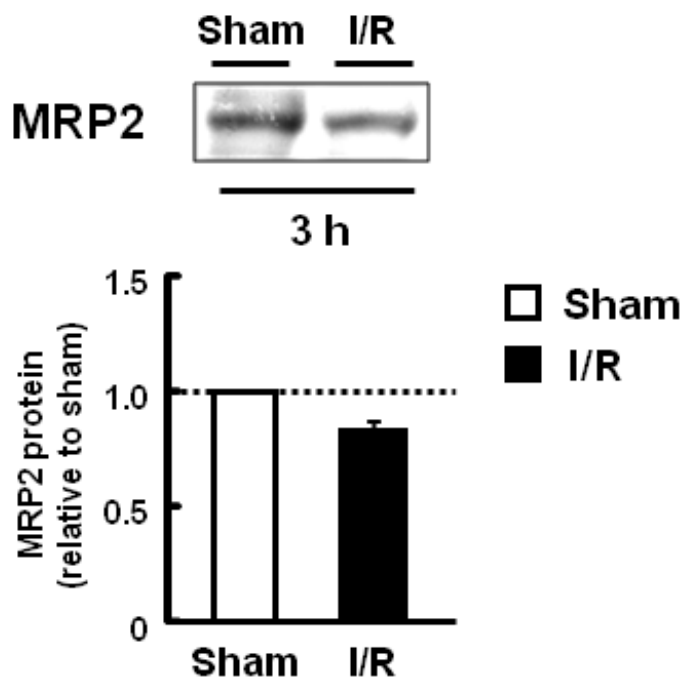

Supplementary Figure 2. MRP2 expression at $3 \mathrm{~h}$ after intestinal I/R. (A) MRP2 mRNA level at $3 \mathrm{~h}$ after intestinal I/R. (B) MRP2 protein expression at $3 \mathrm{~h}$ after intestinal I/R. Each column represents the mean with S.D. of 3-5 measurements. Liver crude membranes at $3 \mathrm{~h}$ after intestinal $\mathrm{I} / \mathrm{R}$ were used for Western blot analysis. Western blot band intensity was determined by densitometry using Scion image program. Statistical significance was evaluated using Student's t-test. **; $\mathrm{P}<0.01$ significantly different from sham.

FXR expression level was increased and PXR expression level was recovered, though CAR expression level was still decreased, suggesting that the recovery of MRP2 expression level after intestinal $\mathrm{I} / \mathrm{R}$ was mainly caused by the increase in
FXR expression level. In the HepG2 cells, FXR expression level was not altered by high concentration IL-6 treatment for $24 \mathrm{~h}$, though that was decreased by low concentration of IL- 6 treatment for $24 \mathrm{~h}$. These results also suggested that the 
maintenances mechanism of FXR protein expression level and activity worked as cellular protection when sever inflammation occurred. This suggestion is also confirmed by the fact that intestinal $\mathrm{I} / \mathrm{R}$ injury was recovered at $24 \mathrm{~h}(24,27)$. The PXR protein expression level was recovered at $24 \mathrm{~h}$ after intestinal $\mathrm{I} / \mathrm{R}$, though PXR mRNA level was still decreased. In the HepG2 cells, PXR protein expression level was recovered with IL-6 treatment for $48 \mathrm{~h}$, though PXR mRNA level was still decreased. These results suggested that PXR protein expression level was recovered by post-transcriptional regulation in IL-6-induced inflammation. The CAR mRNA level and protein expression level were still decreased at 24 $\mathrm{h}$ after intestinal I/R. On the other hand, CAR protein expression level was recovered with IL-6 treatment for $48 \mathrm{~h}$ in HepG2 cells, though CAR mRNA level was still decreased. Thus, we suggested that the decreased in CAR expression level after intestinal I/R was caused by IL- 6 dependent and independent mechanisms.

The amount of IL-6 in the liver homogenate at 6 $\mathrm{h}$ in sham-operated rats was slightly increased than that at the other times in sham-operated rats. We did not investigate the factors inducing the IL-6 production by sham-operation, but it is possible that laparotomy may have contributed to this increment. Indeed, several workers reported that laparotomy induced the stress, and produced several stress hormones, particularly catecholamine and adrenocorticotropin (ACTH) $(29,30)$. These findings suggest that laparotomy may affect the increment of IL-6 by sham operation.

As in the liver, MRP2 expression level in the jejunum has also been shown to be decreased at $6 \mathrm{~h}$ after intestinal I/R (24). However, FXR, PXR and CAR expression levels and localization levels in nuclei in the jejunum were not decreased at any time after intestinal $\mathrm{I} / \mathrm{R}$ (data not shown). These results suggested that decrease in MRP2 expression level after intestinal $\mathrm{I} / \mathrm{R}$ was cause by different mechanism between the jejunum and liver. This difference between the jejunum and liver is not clear. It has been shown that IL-6 receptor expression level is abundant in the liver compared with that in the jejunum (31). This finding may be one of the reasons for the discrepancy between the jejunum and liver after intestinal $\mathrm{I} / \mathrm{R}$.

In conclusion, FXR, PXR and CAR expression levels are decreased in the liver after intestinal $\mathrm{I} / \mathrm{R}$.
IL-6 is one of main causes the decreases in expression levels of these receptors. The decrease in the expression levels of these nuclear receptors causes the decrease in target gene expression level, and might be cause the liver injury after intestinal $\mathrm{I} / \mathrm{R}$.

\section{ACKNOWLEDGEMENT}

This work was supported in part by a grant from the Nakatomi Foundation.

\section{REFERENCES}

1. Sun Z, Wang X, Deng X, Lasson A, Wallén R, Hallberg E, Andersson R. The influence of intestinal ischemia and reperfusion on bidirectional intestinal barrier permeability, cellular membrane integrity, proteinase inhibitors, and cell death in rats. Shock, 1998; 10:203-12.

2. Schmeling DJ, Caty MG, Oldham KT, Guice KS, Hinshaw DB. Evidence for neutrophil-related acute lung injury after intestinal ischemia-reperfusion. Surgery, 1989; 106:195-202.

3. Mutlu G, Abbasoglu L, Dogru-Abbasoglu S, Solakoglu S, Bulut M. Morphologic changes and lipid peroxidation in renal tissues of young rats following intestinal ischemia-reperfusion. Pediatr Surg Int, 2001; 18:337-40.

4. Horie Y, Ishii H. Liver dysfunction elicited by gut ischemia-reperfusion. Pathophysiology, 2001; 8:11-20.

5. Zhi-Yong S, Dong YL, Wang XH. Bacterial translocation and multiple system organ failure in bowel ischemia and reperfusion. J Trauma, 1992; 32:148-53.

6. Giakoustidis AE, Giakoustidis DE, Iliadis S, Papageorgiou G, Koliakou K, Kontos N, Taitzoglou I, Botsoglou E, Papanikolaou V, Atmatzidis K, Takoudas D, Antoniadis A. Attenuation of intestinal ischemia/reperfusion induced liver and lung injury by intraperitoneal administration of (-)-epigallocatechin-3-gallate. Free Radic Res, 2007; 40:103-10.

7. Parks DA, Bulkley GB, Granger DN, Hamilton SR, McCord JM. Ischemic injury in the cat small intestine: role of superoxide radicals. Gastroenterology, 1982; 82:9-15.

8. Deitch EA, Rutan R, Waymack JP. Trauma, shock, and gut translocation, New Horizon, 1996; 4:289-99.

9. Millet P, Moulin M, Stieger B, Daali Y, Pastor CM. How organic anions accumulate in hepatocytes lacking Mrp2: evidence in rat liver. J Pharmacol Exp Ther, 2011; 336:624-32. 
10. Lehmann JM, McKee DD, Watson MA, Willson TM, Moore JT, Kliewer SA. The human orphan nuclear receptor PXR is activated by compounds that regulate CYP3A4 gene expression and cause drug interactions. J Clin Invest, 1998; 102:1016-23.

11. Geick A, Eichelbaum M, Burk O. Nuclear receptor response elements mediate induction of intestinal MDR1 by rifampin. J Biol Chem, 2001; 276:14581-7.

12. Kast HR, Goodwin B, Tarr PT, Jones SA, Anisfeld AM, Stoltz CM, Tontonoz P, Kliewer S, Willson TM, Edwards PA. Regulation of multidrug resistance-associated protein $2(\mathrm{ABCC} 2)$ by the nuclear receptors pregnane $\mathrm{X}$ receptor, farnesoid $\mathrm{X}$-activated receptor, and constitutive androstane receptor. J Biol Chem, 2002; 277:2908-15.

13. Gnerre C, Blättler S, Kaufmann MR, Looser R, Meyer UA. Regulation of CYP3A4 by the bile acid receptor FXR: evidence for functional binding sites in the CYP3A4 gene. Pharmacogenetics, 2004; 14:635-45.

14. Burk O, Arnold KA, Geick A, Tegude H, Eichelbaum $\mathrm{M}$. A role for constitutive androstane receptor in the regulation of human intestinal MDR1 expression. Biol Chem, 2005; 386:503-13.

15. Guo GL, Lambert G, Negishi M, Ward JM, Brewer HB Jr, Kliewer SA, Gonzalez FJ, Sinal CJ. Complementary roles of farnesoid $\mathrm{X}$ receptor, pregnane $\mathrm{X}$ receptor, and constitutive androstane receptor in protection against bile acid toxicity. J Biol Chem, 2003; 278:45062-71.

16. Zhang J, Huang W, Qatanani M, Evans RM, Moore DD. The constitutive androstane receptor and pregnane $\mathrm{X}$ receptor function coordinately to prevent bile acid-induced hepatotoxicity. J Biol Chem, 2004; 279:49517-22.

17. Sinal CJ, Tohkin M, Miyata M, Ward JM, Lambert G, Gonzalez FJ. Targeted disruption of the nuclear receptor FXR/BAR impairs bile acid and lipid homeostasis. Cell, 2000; 102:731-44.

18. Sonoda J, Chong LW, Downes M, Barish GD, Coulter $\mathrm{S}$, Liddle C, Lee CH, Evans RM. Pregnane X receptor prevents hepatorenal toxicity from cholesterol metabolites. Proc Natl Acad Sci U S A, 2005; 102:2198-203.

19. Zhang S, Wang J, Liu Q, Harnish DC. Farnesoid X receptor agonist WAY-362450 attenuates liver inflammation and fibrosis in murine model of non-alcoholic steatohepatitis. J Hepatol, 2009; 51:380-8.

20. Saini SP, Sonoda J, Xu L, Toma D, Uppal H, Mu Y, Ren S, Moore DD, Evans RM, Xie W. A novel constitutive androstane receptor-mediated and
CYP3A-independent pathway of bile acid detoxification. Mol Pharmacol, 2004; 65:292-300.

21. Wagner M, Halilbasic E, Marschall HU, Zollner G, Fickert P, Langner C, Zatloukal K, Denk H, Trauner M. CAR and PXR agonists stimulate hepatic bile acid and bilirubin detoxification and elimination pathways in mice. Hepatology, 2005; 42:420-30.

22. Fang C, Yoon S, Tindberg N, Järveläinen HA, Lindros $\mathrm{KO}$, Ingelman-Sundberg M. Hepatic expression of multiple acute phase proteins and down-regulation of nuclear receptors after acute endotoxin exposure. Biochem Pharmacol, 2004; 67:1389-97.

23. Hartmann G, Cheung AK, Piquette-Miller M. Inflammatory cytokines, but not bile acids, regulate expression of murine hepatic anion transporters in endotoxemia. J Pharmacol Exp Ther, 2002; 303:273-81.

24. Ogura J, Kobayashi M, Itagaki S, Hirano T, Iseki K. Alteration of Mrp2 and P-gp expression, including expression in remote organs, after intestinal ischemia-reperfusion. Life Sci, 2008; 82:1242-8.

25. Deryckere F, Gannon F. A one-hour minipreparation technique for extraction of DNA-binding proteins from animal tissues. BioTechniques, 1994; 16:405.

26. Lowry OH, Rosebrough NJ, Farr AL, Randall RJ. Protein measurement with the Folin phenol reagent. J Biol Chem, 1951; 193:265-75.

27. Ucan HB, Kaplan M, Salman B, Yilmaz U, Mentes BB, Aybay C. Effect of oophorectomy and exogenous estrogen replacement on liver injury in experimental obstructive jaundice. World J Gastroenterol, 2008; 14:2818-24.

28. Ogura J, Fujikawa A, Maruyama H, Kobayashi M, Itagaki A, Iseki K. Alteration of P-gp expression after intestinal ischemia-reperfusion following 16-h fasting in rats. Yakugaku Zasshi, 2011; 131:453-62.

29. Muzii L, Marana R, Marana E, Paielli FV, Meo F, Maussier ML, Sciarra M, Mancuso S. Evaluation of stress-related hormones after surgery by laparoscopy or laparotomy. J Am Assoc Gynecol Laparosc, 1996; 3:229-34.

30. Geier A, Dietrich CG, Trauner M, Gartung C. Extrahepatic cholestasis downregulates Oatp1 by TNF-alpha signalling without affecting Oatp2 and Oatp4 expression and sodium-independent bile salt uptake in rat liver. Liver Int, 2007; 27:1056-65.

31. Kato A, Watanabe T, Yamazaki M, Deki T, Suzuki M. IL-6R distribution in normal human and cynomolgus monkey tissues. Regul Toxicol Pharmacol, 2009; 53:46-51. 